\title{
Keputusan Pembelian Lipstik Ditinjau dari Persepsi Konsumen pada Mahasiswi Fakultas Ekonomi Universitas Pelita Harapan Medan
}

\section{Purchase Decision Lipstick In Terms Of Consumer Perception of Student Faculty Economy University Pelita Harapan Medan}

\author{
Achmad Irvan Dwi Putra, Octaniani Chiwnita*\& Sarinah \\ Program Studi Psikologi, Fakultas Psikologi, Universitas Prima Indonesia, Indonesia
}

Diterima: Mei 2019; Disetujui: Juli 2019; Dipublish: Agustus 2019

*Coresponding Email: octaniani.chiwnita@gmail.com

\begin{abstract}
Abstrak
Penelitian ini bertujuan untuk mengetahui hubungan antara persepsi konsumen dengan keputusan pembelian pada mahasiswi fakultas ekonomi Universitas Pelita Harapan Medan. Hipotesis yang diajukan dalam penelitian ini adalah ada hubungan positif antara persepsi konsumen dengan keputusan pembelian dengan asumsi bahwa semakin tinggi persepsi konsumen, maka semakin tinggi juga keputusan pembelian dan begitu pula sebaliknya. Subjek penelitian yang digunakan dalam penelitian ini adalah Mahasiswi Fakultas Ekonomi Universitas Pelita Harapan Medan sebanyak 123 orang. Data diperoleh dari skala untuk mengukur persepsi konsumen dan keputusan pembelian Analisis data yang digunakan adalah menggunakan korelasi Product Moment (Pearson Correlation). Hasil analisis data menunjukkan koefisien korelasi sebesar 0,510 dan nilai signifikansi sebesar 0,000 (p $<0,05)$. Hasil analisis data tersebut menunjukkan adanya hubungan positif antara persepsi konsumen dengan keputusan pembelian. Hasil penelitian juga menunjukkan bahwa sumbangan efektif yang diberikan persepsi konsumen terhadap keputusan pembelian adalah sebesar 26.1 persen, selebihnya 73.9 persen dipengaruhi oleh faktor lain yang tidak diteliti. Dari hasil penelitian ini dapat disimpulkan bahwa hipotesis penelitian ada hubungan yang positif antara persepsi konsumen dengan keputusan pembelian.
\end{abstract}

Kata Kunci: Keputusan Pembelian, Persepsi Konsumen

\begin{abstract}
This study aims to determine the relationship between consumer perception and purchase decision of Economics Faculty Students of Pelita Harapan University Medan. The hypothesis proposed in this research is there any positive correlation between perception consumer and purchase decision of Economics Faculty Students of Pelita Harapan University Medan, assuming that the higher consumer perception, the higher the purchase decision, and vice versa. The sample of this research is as many as 123 students. This research used purchase decision and consumer perception scale. Product Moment (Pearson Correlation) was used to analyze the correlation between two variables. The results of the data analysis showed that the correlation coefficient was 0,510 with a significance value of $0.000(p<0.05)$. It shows that there is a positive correlation between consumer perception and purchase decision. The results of data analysis showed a correlation correlation coefficient of $0.261(p<0.05)$ and showed that the contribution of a given perception consumer on purchase decision was 26.1 percent, while the remaining 73.9 percent was affected by other factors not examined. From the results, it can be concluded that the hypothesis stating that there is a significance relationship between consumer perception and purchase decision.
\end{abstract}

Keywords: Purchase Decision, Consumer Perception

How to Cite: Putra, A.I.D. Chiwnita, O. \& Sarinah. (2019). Keputusan Pembelian ditinjau dari Persepsi Konsumen pada Mahasiswi Fakultas Ekonomi Universitas Pelita Harapan Medan. Journal of Education, Humaniora and Social Sciences (JEHSS). 2 (1): 55 - 63.

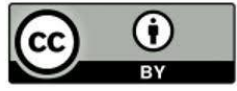




\section{PENDAHULUAN}

Semua individu baik dari usia muda sampai tua merupakan seorang konsumen. Semua individu membeli atau memperoleh barang atau jasa untuk dikonsumsi pribadi. Setiap individu mengkonsumsi suatu produk sesuai kebutuhan sehari-hari nya dan tentu juga memiliki selera yang berbeda-beda tergantung dari persepsi, konsep diri, sikap, gaya hidup, dan kepribadian konsumen (Yuniarti, 2015).

Pasar atau market berperan penting dalam kehidupan konsumen. Masyarakat dapat memilih tempat belanjanya sesuai keinginan dan selera masing-masing. Pasar merupakan tempat dimana konsumen dengan kebutuhan dan keinginannya bersedia dan mampu untuk terlibat dalam pertukaran guna memenuhi kebutuhan dan keinginan tersebut. Konsumen biasanya berbelanja langsung di suatu toko yang biasa disebut dengan marketplace, yaitu bersifat fisik seperti seseorang berbelanja di suatu toko (Priansa, 2017).

Semakin pesat perkembangan zaman, dengan adanya teknologi yang canggih konsumen tidak perlu menghabiskan waktunya untuk datang ke toko lagi. Pesatnya perkembangan bisnis online di tanah air juga didukung dalam penggunaan telepon seluler atau smartphone sehingga mempercepat pertumbuhan pengguna internet Indonesia. Jumlah pengguna internet di Indonesia didominasi kalangan masyarakat kelas menengah dengan rentang usia 15-35 tahun. Hal inilah yang menjadi alasan mengapa sasaran pemasaran produk via internet kebanyakan ditujukan kepada konsumen berusia muda, sebab konsumen berusia tua pada umumnya kurang akrab dengan model belanja online (www.kompas.com).

Saat ini perkembangan teknologi membawa perubahan pada gaya hidup remaja (Susianto dalam Yuniarti, 2015). Gaya hidup remaja pada saat ini sangat dipengaruhi oleh perkembangan lingkungan sosial. Mereka sangat memerhatikan mode atau tren yang sedang berlangsung (Prezz dalam Yuniarti, 2015). Oleh karena itu remaja merupakan target pemasaran berbagai produk industri karena karakteristik remaja yang cenderung labil dan mudah dipengaruhi. Remaja putri merupakan pembeli yang potensial untuk produk-produk bermerek, seperti pakaian, sepatu, aksesoris, dan kosmetik. Gorrese dan Ruggieri (dalam Santrock, 2014) menyatakan bahwa remaja putri menunjukkan kelekatan pada teman sebaya yang lebih tinggi, terutama berkaitan dengan kepercayaan dan komunikasi. Pemikiran remaja putri pada umumnya berpusat 
pada berpacaran, berbelanja, dan penampilan fisik mereka (Campbell dalam Santrock, 2014).

Pemikiran remaja putri berpusat pada berbelanja dan penampilan fisik mereka yang dipengaruhi oleh perkembangan lingkungan sosial. Membeli pakaian, aksesoris dan kosmetik serta mempercantik wajah maupun tubuh merupakan hal yang tidak dapat dihindari oleh para remaja saat ini. Namun kegiatan tersebut terkadang membawa penyesalan terhadap diri remaja.

Hal ini diungkapkan oleh Fatya Biya dengan rasa kecewa dan menyesalinya setelah membeli foundation palsu di salah satu online shop, yang awalnya Fatya mengira adalah produk asli karena melihat review yang diberikan oleh penjual online shop sangat bagus dan menjamin foundation tersebut asli karena harga yang diberikan cukup mahal. Fatya pun langsung membelinya tanpa adanya keraguan lagi. Pada akhirnya foundation telah dicoba oleh Fatya dan setelah dipakai ternyata teksturnya sangat kasar dan kulit wajahnya setelah memakai foundation menjadi kasar. Kemudian Fatya pun membeli foundation tersebut asli dari toko distributornya langsung, dan Fatya membandingkan foundation yang ia beli keduanya, ternyata hasil yang didapatkan benar foundation yang ia beli langsung di toko teksturnya lembut dan setelah memakainya kulit wajah Fatya pun tidak kasar seperti yang ia beli di online shop. Kemudian Fatya memutuskan untuk tidak membeli produk kecantikan di online shop lagi (www.famous.id).

Kasus lain yang serupa terjadi oleh Asmidah yang masih berusia 21 tahun yang menyesali membeli krim kecantikan. Awalnya Asmidah memakai krim kecantikan ini karena diyakini oleh penjualnya dapat memuluskan wajah dan membuat wajah menjadi putih bersih. Seiring berjalannya waktu memang awalnya Asmidah memakai krim ini tidak masalah namun setelah beberapa bulan ia merasakan gatal-gatal diseluruh wajahnya dan setelah mengalami kegatalan, wajahnya menjadi merah-merah dan bermunculan banyak jerawat hampir diseluruh wajahnya. Asmidah pun pergi ke dokter kulit dan dokter mengatakan kandungan krim yang selama ini dipakai tidak cocok dengan kulit Asmidah. Akhirnya Asmidah berhenti memakai krim kecantikan apapun (www.tribunsumsel.com).

Penyesalan pembelian juga dirasakan oleh mahasiswi Fakultas Ekonomi di Universitas Pelita Harapan (UPH) Medan. Berdasarkan hasil wawancara terhadap salah satu mahasiswi yang masih berusia 20 tahun mengaku bahwa dirinya kebanyakan 
membeli produk kecantikan tanpa mempertimbangkan kualitas terlebih dahulu melainkan membelinya berdasarkan ketertarikan persuasif dari para penjual. Mereka membeli produk tanpa mempertimbangkan kualitas terlebih dahulu itu sangat disesali oleh mahasiswi.

Mengacu pada kasus di atas, dapat disimpulkan bahwa pembelian yang didasarkan pada persepsi konsumen tanpa mempertimbangkan aspek lain seperti pengalaman, selektif dan evaluatif dapat menimbulkan kekecewaan pada diri konsumen. Konsumen mempunyai pengalaman pribadi tentang kebutuhan produk yang sedang mereka rasakan. Apabila mereka mengingat produk masa lampau dapat memenuhi kebutuhan tersebut secara memuaskan, mereka mencantumkan produk tersebut dalam daftar pilihan produk. Pengalaman konsumen mengonsumsi produk (positif atau negatif) berpengaruh dalam pengambilan keputusan membeli.

Keputusan pembelian merupakan tahap dari proses keputusan pembeli dimana konsumen benar-benar membeli produk (Kotler, dkk., 2012). Selain itu keputusan pembelian dapat didefinisikan sebagai tahap-tahap yang dilalui oleh pembeli dan melakukan pembelian produk dan jasa (Belch \& Belch, 2003). Keputusan pembelian memiliki hubungan yang terkait dengan pemasaran produk atau jasa seperti pola pembelian, proses keputusan konsumen dan faktor yang mempengaruhi keputusan konsumen dipengaruhi oleh persepsi mereka untuk membuat keputusan pembelian (Belch \& Belch, 2003).

Penelitian yang dilakukan oleh Mantik, dkk., (2015) kepada 100 responden di KFC Megamall Manado membuktikan bahwa terdapat pengaruh positif antara persepsi konsumen dengan keputusan pembelian. Dari penelitian tersebut juga disebutkan perusahaan harus menyediakan sesuatu yang khusus sebagai stimuli untuk menarik perhatian dari persepsi konsumen, apabila persepsi konsumen meningkat, maka keputusan pembelian juga meningkat. Dari pernyataan tersebut, dapat disimpulkan bahwa salah satu faktor dari keputusan pembelian adalah persepsi konsumen.

Robbins (dalam Yuniarti, 2015) mendefinisikan persepsi konsumen adalah proses seorang konsumen untuk mengorganisasikan dan mengartikan kesan dari pancai ndera dalam tujuan untuk memberi arti dalam lingkungan mereka. Kasali (dalam Sumarwan, 2012) juga menyatakan bahwa persepsi konsumen merupakan suatu proses dimana 
individu terekspos secara informasi, menyediakan kapasitas prosesor yang lebih luas dan menginterpretasikan informasi tersebut.

Penelitian terdahulu telah membuktikan bahwa persepsi konsumen mempengaruhi keputusan pembelian. Salah satu hasil penelitian yang dilakukan oleh Huriartanto, dkk., (2015) kepada 100 responden di terminal Malang membuktikan bahwa terdapat pengaruh positif dan signifikan antara persepsi konsumen terhadap keputusan pembelian. Semakin tinggi persepsi konsumen terhadap suatu produk maka semakin tinggi juga untuk keputusan konsumen melakukan pembelian.

Terdapat faktor lain yang mempengaruhi keputusan pembelian selain persepsi konsumen, yaitu citra merek dan harga. Penelitian yang dilakukan oleh Prasastiningtyas (2016) pada 100 orang pelanggan kartu seluler Telkomsel pada karyawan PT. Sentral Bahana Ekatama membuktikan bahwa citra merek dan harga berpengaruh positif dan signifikan terhadap keputusan pembelian. Konsumen menjadikan citra merek sebagai acuan sebelum melakukan pembelian. Harga yang diinginkan konsumen adalah harga yang bersahabat, semakin cocok harga dari suatu produk, maka semakin tinggi keputusan konsumen untuk melakukan pembelian.

Berdasarkan uraian di atas, maka peneliti tertarik merasa tertarik untuk meneliti dan membahas lebih jauh tentang pengaruh persepsi konsumen terhadap keputusan pembelian. Adapun tujuan pelaksanaan penelitian ini adalah untuk mengetahui hubungan antara persepsi konsumen dengan keputusan pembelian. Penelitian ini diharapkan dapat berguna dan bermanfaat bagi perkembangan teori di bidang ilmu Psikologi pada umumnya dan khususnya bagi Psikologi Industri dan Organisasi dan Psikologi Konsumen. Penelitian ini diharapkan untuk menambah pengetahuan konsumen tentang persepsi yang dapat mempengaruhi keputusan pembelian, sehingga konsumen dapat menjadi selektif dalam membeli produk. Serta bagi perusahaan diharapkan untuk menambah pengetahuan perusahaan mengenai pengaruh persepsi konsumen terhadap keputusan pembelian. Sehingga perusahaan dapat meningkatkan produktivitasnya dengan cara mempengaruhi persepsi konsumen.

Berdasarkan tinjauan teoritis yang telah diuraikan di atas, hipotesa yang dapat diajukan dalam penelitian ini adalah sebagai berikut: ada hubungan positif antara persepsi konsumen dengan keputusan pembelian, dengan asumsi semakin tinggi 
persepsi konsumen maka semakin tinggi keputusan pembelian. Sebaliknya semakin rendah persepsi konsumen maka semakin rendah keputusan pembelian.

\section{METODE PENELITIAN}

Penelitian ini menggunakan jenis penelitian deskriptif kuantitatif yaitu penelitian korelasional, sesuai dengan permasalahan dan tujuan dari penelitian. Adapun variabel dalam penelitian ini yaitu persepsi konsumen sebagai variabel bebas dan variabel terikat adalah keputusan pembelian. Populasi dalam penelitian ini adalah seluruh mahasiswi Fakultas Ekonomi Universitas Pelita Harapan Medan angkatan tahun 2016 yang berjumlah 123 orang. Teknik pengambilan sampel yang digunakan adalah purposive sampling.

Skala yang digunakan dalam penelitian ini yaitu menggunakan dua skala, yaitu skala keputusan pembelian dan skala persepsi konsumen. Skala ukur keputusan pembelian dalam penelitian ini disusun berdasarkan 7 (tujuh) dimensi yang dikemukakan oleh Schiffman dan Kanuk (2012) yaitu masukan pemasaran, masukan sosiobudaya, pengenalan kebutuhan, penelitian sebelum pembelian, penilaian alternative, perilaku pembelian, dan penilaian pasca-pembelian. skala keputusan pembelian yang terdiri dari 36 butir pernyataan, dengan 17 butir pernyataan favorable dan 19 butir Unfavourable.

Skala ukur persepsi konsumen dalam penelitian ini disusun berdasarkan 3 (tiga) dimensi yang dikemukakan oleh Priansa (2017), yaitu penginderaan (sensasi), atensi, interpretasi. Skala persepsi konsumen yang terdiri dari 22 butir pernyataan, dengan 13 butir pernyataan favorable dan 9 butir Unfavourable.

Teknik analisis yang digunakan untuk menganalisis data hasil penelitian ini adalah teknik korelasi analisis product moment.

\section{HASIL DAN PEMBAHASAN}

\section{Analisa Deskriptif Keputusan Pembelian dan Persepsi Konsumen}

Tabel 1. Statistik Deskriptif

\begin{tabular}{lccc}
\hline & \multicolumn{3}{c}{ Descriptive Statistics } \\
\hline & $\boldsymbol{N}$ & Mean & Std. Deviation \\
Keputusan Pembelian & 123 & 106.24 & 7.716 \\
Persepsi Konsumen & 123 & 66.52 & 6.441 \\
\hline
\end{tabular}


Tabel 1 merupakan statistik deskriptif variabel keputusan pembelian dan persepsi konsumen. Tabel ini menunjukkan variabel keputusan pembelian memiliki nilai rata-rata 106,24 dengan standar deviasi 7,716. Sedangkan pada variabel persepsi konsumen memiliki nilai rata-rata 66,52 dengan standar deviasi 6,441.

Tabel 2. Kriteria Tingkat Keputusan Pembelian dan Persepsi Konsumen

\begin{tabular}{lllll}
\hline Variabel & Rentang Nilai & Kategori & Jumlah $(\mathbf{n})$ & Persentase \\
\hline Keputusan & $\mathrm{x}<72$ & Rendah & $\mathrm{o}$ & $\mathrm{o} \%$ \\
Pembelian & $72 \leq \mathrm{x}<108$ & Sedang & 74 & $60.16 \%$ \\
& $\mathrm{x} \geq 108$ & Tinggi & 49 & $39.84 \%$ \\
& Jumlah & & 123 & $100 \%$ \\
& $\mathrm{x}<44$ & Rendah & $\mathrm{o}$ & $\mathrm{0} \%$ \\
Persepsi & $44 \leq \mathrm{x}<66$ & Sedang & 64 & $52.03 \%$ \\
Konsumen & $\mathrm{x} \geq 66$ & Tinggi & 59 & $47.97 \%$ \\
& Jumlah & & 123 & $100 \%$
\end{tabular}

Tabel 2 merupakan kriteria tingkat keputusan pembelian dan persepsi konsumen. Tabel ini menunjukkan rata-rata keputusan pembelian berada pada kategori tinggi dengan presentase sebesar 39,84\%. Sedangkan rata-rata persepsi konsumen berada pada kategori tinggi dengan presentase sebesar 47,97\%. Penelitian ini adalah penelitian korelasional yang digunakan untuk mengetahui ada atau tidaknya korelasi antara keputusan pembelian dan persepsi konsumen. Namun sebelum dilakukan uji korelasi, peneliti melakukan uji asumsi terlebih dahulu untuk menentukan jenis statistik parametik atau non-parametik yang akan digunakan untuk uji korelasi.

Uji normalitas dilakukan agar dapat mengetahui apakah setiap variabel penelitian telah menyebar secara normal atau tidak. Uji normalitas sebaran menggunakan uji Kolmogorov Smirnov Test. Data dikatakan berdistribusi normal jika p > 0.05 (Priyatno, 2017). Uji normalitas yang dilakukan terhadap variabel keputusan pembelian diperoleh koefisien KS-Z = 773 dengan Sig sebesar 0.588 untuk uji 2 (dua) arah, sedangkan penelitian ini memiliki hipotesis satu arah, sehingga yang dipakai adalah uji 1 (satu) arah/ Sig 1-tailed sebesar 0.294 ( $\mathrm{p}>0.05$ ), yang berarti bahwa data pada variabel keputusan pembelian memiliki sebaran atau berdistribusi normal. Uji normalitas pada variabel persepsi konsumen diperoleh koefisien KS-Z = 988 dengan Sig sebesar 0.283 untuk uji 2 (dua) arah, sedangkan penelitian ini memiliki hipotesis satu arah, sehingga yang dipakai adalah uji 1 (satu) arah/ Sig 1-tailed sebesar 0.1415 ( $\mathrm{p}>0.05$ ), yang berarti bahwa data pada variabel persepsi konsumen memiliki sebaran atau berdistribusi normal. 
Tabel 3. Hasil Uji Normalitas

\begin{tabular}{llllll}
\hline Variabel & SD & KS-Z & Sig. & p & Keterangan \\
\hline KeputusanPembelian & 7.716 & 0.773 & 0.294 & p $>0.05$ & Sebaran normal \\
Persepsi Konsumen & 6.441 & 0.988 & 0,1415 & p $>0.05$ & Sebaran normal \\
\hline
\end{tabular}

Dari hasil uji normalitas data, didapat hasil data berdistribusi normal pada kedua variabel, jadi uji korelasi yang digunakan dalam penelitian ini adalah korelasi Product Moment. Berdasarkan hasil analisis korelasi antara persepsi konsumen dengan keputusan pembelian, diperoleh koefisien korelasi Product Moment sebesar 0,510 dengan sig sebesar 0,000 ( $p<0,05$ ). Hasil tersebut menunjukkan bahwa adanya hubungan positif antara persepsi konsumen dengan keputusan pembelian. Dari hasil perhitungan tersebut, maka hipotesis yang diajukan dalam penelitian ini menunjukkan adanya hubungan positif antara persepsi konsumen dengan keputusan pembelian diterima.

\section{SIMPULAN}

Berdasarkan hasil-hasil yang telah diperoleh dalam penelitian ini, maka dapat disimpulkan bahwa terdapat hubungan yang positif antara persepsi konsumen dengan keputusan pembelian. Hasil Penelitian yang telah dilakukan kepada 123 mahasiswi fakultas ekonomi universitas Pelita Harapan Medan menunjukkan bahwa terdapat hubungan yang signifikan antara antara persepsi konsumen dengan keputusan pembelian. Dengan nilai koefisien sebesar 0.510 dengan sig. $0.000(p<0.005)$, dapat diartikan keputusan pembelian dan persepsi konsumen memiliki hubungan positif. Analisis data yang digunakan pada penelitian ini adalah korelasi Product Moment (Pearson Correlation). Hasil penelitian juga menunjukkan bahwa sumbangan efektif yang diberikan persepsi konsumen terhadap keputusan pembelian adalah sebesar 26.1 persen, selebihnya 73.9 persen dipengaruhi oleh faktor lain yang tidak diteliti. Dari hasil penelitian ini dapat disimpulkan bahwa hipotesis penelitian ada hubungan yang positif antara persepsi konsumen dengan keputusan pembelian.

\section{DAFTAR PUSTAKA}

Agustian, W. (2013). Pengaruh Persepsi Konsumen Terhadap Keputusan Pembelian Di Indomaret Unit Panjaitan 2 Plaju Palembang. Seminar Nasional Informatika 2013 (semnasIF 2013) UPN “Veteran”Yogyakarta, 18 Mei 2013. ISSN : 1979-2328.

Azwar, S. (2012). Penyusunan Skala Psikologi, Edisi 2. Yogyakarta : Pustaka Pelajar.

Belch, G. E. \& Belch M. A. (2003). Advertising and Promotion : An Integrated Marketing Communications Perspective,Sixth Edition. New York : McGraw-Hill Education. 
Darmansyah., Salim, M., \& Bachri, S. (2014.) Pengaruh Celebrity Endorser terhadap Keputusan Pembelian Produk di Indonesia (Penelitian Online). Jurnal Aplikasi Manajemen, Volume 12, Nomor 2

Devina, P. \& Andreani, F. (2006). Pengaruh Marketing Mix Terhadap Keputusan Pembelian di Susan Spa and Resort Bandungan. Jurnal Teknik Elektro Vol.6, No. 1

Huriartanto, A., Hamid, D., \& Shanti, P. (2015). Pengaruh Motivasi dan Persepsi Konsumen Terhadap Keputusan Pembelian Tiket Pesawat. Jurnal Administrasi Bisnis, Vol.8, No.1

Kaharu, D. (2016). Pengaruh Gaya Hidup, Promosi, dan Kualitas Produk Terhadap Keputusan Pembelian Pada Cosmic. Jurnal Ilmu dan Riset Manajemen, Volume 5, Nomor 3

Kotler, P. \& Amstrong, G. (2012). Principles of Marketing. 14th ed. New Jersey : Pearson Education, Inc.

Mantik, A. F., Mananeke, L., \& Tawas, H. (2015). Pengaruh Motivasi dan Persepsi konsumen Terhadap Keputusan Pembelian di KFC Megamall Manado. Jurnal EMBA, Vol.3 No.1.

Muanas, A. \& Suhermin. (2014). Pengaruh Produk, Harga, dan Promosi Terhadap Keputusan Pembelian Mobil Buana Indomobil Trada. Jurnal Ilmu \& Riset Manajemen, Vol. 3, No. 12.

Njoto, T. K. (2016). Pengaruh Desain Kemasan, Cita Rasa, dan Variasi Produk Terhadap Keputusan Pembelian Bumi Anugerah. Jurnal Manajemen, Volume 1, Nomor 4.

Nugraha, F. A. A., Suharyono., \& Kusumawati, A. (2015). Pengaruh Word Of Mouth Terhadap Keputusan Pembelian dan Kepuasan Konsumen pada Konsumen Kober Mie Setan jalan Simpang Soekarno-Hatta nomor 1-2 Malang. Jurnal Administrasi Bisnis, Vol. 22, No. 1.

Prasastiningtyas, T. R. (2016). Pengaruh Citra Merek, Kualitas Produk, dan Harga Terhadap Keputusan Pembelian Kartu Seluler. Jurnal Ilmu dan Riset Pemasaran, Volume 5, Nomor 7.

Priansa, D. J. (2017). Perilaku Konsumen dalam Persaingan Bisnis Kontemporer. Bandung : Alfabeta.

Priyatno, D. (2017). Buku Saku Analisis Statistik Data SPSS. Yogyakarta : MediaKom.

Santrock, J. W. (2014). Adolescence, Fifteenth Edition. New York : McGraw-Hill Education.

Sanusi, A. (2011). Metodologi Penelitian Bisnis. Jakarta : Salemba Empat.

Schiffman, L. G., \& Kanuk, L. L. (2012). Consumer Behaviour: a European Outlook Second Edition. New York : Pearson Education Limited.

Silva, P. M. (2017). Pengaruh Persepsi Konsumen dan Motivasi Konsumen Terhadap Keputusan Pembelian Polis Asuransi Pada Nasabah Asuransi Prudential di Kota Samarinda. Jurnal Psikologi, Volume 5, Nomor 3.

Sugiyono. (2013). Metode Penelitian Manajemen. Bandung : Alfabeta.

Sumarwan, U. (2012). Riset Pemasaran dan Konsumen. Bogor : IPB Press.

Wulandari, N. M. R. \& Nurcahaya, I. K. (2015). Pengaruh Celebrity Endorser, Brand Image, Brand Trust Terhadap Keputusan Pembelian Clear Shampoo di Kota Denpansar. E-Jurnal Manajemen Unud, Vol. 4, No.11.

Yuniarti, V. S. (2015). Perilaku Konsumen Teori dan Praktik. Bandung : CV Pustaka Setia.

Famous.id. (2017). Fatya Biya Berbagi Pengalaman Ditipu Online Shop Makeup Palsu. Diakses tanggal 19 September dari: https:/famous.brilio.net/video/discover/fatya-biya-berbagi-pengalaman-ditipu-onlineshop-makeup-palsu-180625i.html.

Kompas.com. (2012). Bisnis Online dan Transaksi Elektronik. Diakses tanggal 1 April 2018 dari: http://carajualandiinternet.com/bisnis-online-dan-transaksi- eletronik.

Tribunsumsel.com. (2016). Gara-Gara Krim Kecantikan Wajah Gadis Cantik Ini Hancur dan Jerawatan. Diakses tanggal 19 September dari: http://sumsel.tribunnews.com/2016/07/26/mengerikan-gara-gara-krimkecantikan-wajah-gadis-cantik-ini-hancur-dan-jerawatan. 